\title{
PENYISIHAN NITROGEN TOTAL DALAM LIMBAH CAIR HOTEL DENGAN SISTEM MOVING BED BIOFILM REACTOR MENGGUNAKAN Chlorella sp.
}

\author{
Mustika Chairani, Shinta Elystia*, Sri Rezeki Muria \\ Program Studi Teknik Lingkungan \\ Universitas Riau \\ Pekanbaru, Indonesia \\ e-mail: *shintaelystia@yahoo.com, Chairanimustika@gmail.com, \\ sri_muria@gmail.com
}

\begin{abstract}
Abstrak
Limbah cair hotel dapat dimanfaatkan oleh mikroalga Chlorella sp. sebagai sumber nutrisi bagi pertumbuhannya sehingga dapat menurunkan kadar nitrogen total. Salah satu proses pengolahan limbah yang dapat meningkatkan pertumbuhan mikroalga yaitu Moving Bed Biofilm Reactor. Pada prinsipnya, Moving Bed Biofilm Reactor merupakan pertumbuhan suspensi yang ditingkatkan dengan menambahkan biocarrier di dalam reaktor sebagai tempat perkembangbiakan mikroorganisme, sehingga terjadi dua proses pengolahan yakni pertumbuhan suspensi dan pertumbuhan melekat. Penelitian ini mempelajari pengaruh volume pengisian biocarrier Kaldnes 1 (K1) terhadap penurunan kadar nitrogen total dalam limbah cair hotel. Penelitian ini dilakukan secara batch dengan perlakuan volume pengisian Kaldnes 1 (K1) terhadap penurunan kadar nitrogen total dalam limbah cair hotel dengan 4 level yang berbeda, yaitu 0\% (tanpa penambahan Kaldnes 1 (K1)), volume pengisian Kaldnes 1 (K1) sebanyak 10\%, 20\%, 30\% (volume limbah). Proses pengolahan dilakukan selama 5 hari dengan penyinaran cahaya matahari dalam MBBR. Perlakuan dengan volume pengisian Kaldnes 1 (K1) 20\% mampu menyisihkan nitrogen total dengan efisiensi penyisihan sebesar $91,96 \%$ pada waktu kontak terbaik yaitu hari ke-5.
\end{abstract}

Kata kunci: Chlorella sp., MBBR, Limbah Cair Hotel, Nitrogen Total

\begin{abstract}
Hotel wastewater can be utilized by microalgae Chlorella sp. as a source of nutrition for its growth so its reduce total nitrogen levels. One of the wastewater treatment processes that can increase the growth of microalgae is the Moving Bed Biofilm Reactor. In principle, Moving Bed Biofilm Reactor is suspended growth that is increased by adding biocarriers in the reactor as a place for the propagation of microorganisms, so there are two treatment process happened inside, suspended growth and attached growth. The purposes of this research is to know the effect of biocarrier Kaldnes 1 (K1)) filling volume to decreasing organic content in hotel wastewater. This study conducted in batches by varying of Kaldnes 1 (K1)), Kaldnes 1 (K1) filling volume as many as $10 \%, 20 \%$, and $30 \%$ (wastewater volume). The processing is carried out for 5 days with solar irradiation in the MBBR. The treatment with $20 \%$ Kaldnes 1 (K1) filling volume was able to reduce total nitrogen with $91,96 \%$ removal efficiency at the best removing contact time, happened in days -5 .
\end{abstract}

Keywords : Chlorella sp., MBBR, Hotel Wastewater, Total Nitrogen 


\section{PENDAHULUAN}

Pembangunan hotel di Kota Pekanbaru meningkat $13,75 \%$ rata-rata pertahunnya seiring dengan jumlah limbah cair yang dihasilkan (Pemerintah Kota Pekanbaru, 2017). Hotel-hotel tertentu membuang air limbah secara langsung tanpa pengolahan terlebih dahulu yang dapat menyebabkan tingginya kadar pencemar dalam badan air. Konsentrasi bahan pencemar yang tinggi akan menyebabkan masalah bagi badan air, yaitu dapat menurunkan kandungan Dissolved Oxygen (DO), memicu terjadinya eutrofikasi dan meningkatkan kadar toksisitas badan air, sehingga diperlukan pengolahan limbah yang tepat dalam menyisihkan bahan pencemar (Anisa dan Herumurti, 2017).

Salah satu cara untuk mereduksi bahan pencemar dalam limbah cair hotel adalah dengan memanfaatkan pengolahan biologis (Rekabi, 2015 dalam Imania dan Herumurti, 2018). Pengolahan biologis yang dapat digunakan adalah pengolahan biologis berbasis biofilm. Jenis pengolahan biologis berbasis biofilm yang biasanya digunakan adalah trickling filter, rotating biological contactors (RBC), dan granular media biofilters. Tetapi, ada beberapa kelemahan dalam menggunakan proses pengolahan limbah berbasis biofilm tersebut antara lain volume kerja tidak efektif dengan trickling filter, kerusakan mekanis sering dialami RBC, dan granular media biofilters membutuhkan backwash sehingga pengoperasiannya sering berhenti. Untuk mengatasi kelemahan tersebut, maka dilakukan proses pengolahan limbah menggunakan Moving Bed Biofilm Reactor (MBBR) (Pinjankar, 2017).

MBBR adalah pengolahan biologis kombinasi yang menggunakan konsep pertumbuhan tersuspensi seperti pada lumpur aktif konvensional dan melekat seperti pada biofilter (Ningtias dkk, 2015). Prinsip kerja MBBR didasari pada penggunaan media sebagai tempat perkembangbiakan mikroorganisme (Said dan Santoso, 2015). Media dijaga agar terus bergerak di dalam tangki aerasi sehingga biomassa akan tumbuh membentuk biofilm di permukaannya
(Imania dan Herumurti, 2018). Biomassa yang potensial adalah mikroalga.

Mikroalga menghasilkan Soluble Algal Products (SAP) ekstraseluler yang terdiri dari protein dan polisakarida yang berguna dalam proses melekatnya mikroalga pada permukaan media biocarrier (Wang dkk, 2018). Mikroalga Chlorella sp. memiliki kandungan protein $55-60 \%$ (Paniagua, 2015) dan polisakarida $18-22 \%$ (Sui, 2012) sehingga memiliki kemampuan untuk melekat yang cukup tinggi

Media biocarrier yang seringkali digunakan adalah media biofilm Kaldnes 1 (K1), media ini memiliki luas permukaan \pm $500 \mathrm{~m}^{2} / \mathrm{m}^{3}$ sehingga dapat menyediakan luas permukaan yang cukup besar untuk melekatnya mikroalga membentuk biofilm. Biofilm yang ideal pada MBBR adalah tipis dan terdistribusi secara merata pada permukaaan media (carrier) sehingga volume pengisian biocarrier pada reaktor perlu disesuaikan dengan turbulensi yang tersedia untuk menyalurkan substrat ke biofilm dan mempertahankan ketebalan yang rendah pada biofilm (Said dan Sya'bani, 2014).

Pada penelitian ini akan dipelajari mengenai pengolahan limbah cair hotel menggunakan MBBR bertujuan untuk mengetahui pengaruh volume pengisian media biocarrier Kaldnes 1 (K1) terhadap penyisihan kadar nitrogen total, mlss, suhu, $\mathrm{pH}$ dan jumlah sel Chlorella sp. dalam limbah cair hotel. Selain itu, pada penelitian ini akan dilihat pengaruh waktu kontak terhadap penyisihan parameter pencemar dalam limbah cair hotel. Dengan penelitian ini diharapkan dapat mengatasi pencemaran perairan yang diakibatkan oleh limbah cair hotel dengan pengolahan biologi berbasis mikroalga menggunakan MBBR.

\section{METODE}

\section{Alat}

Proses penyisihan nitrogen total dalam limbah cair hotel dilakukan di dalam MBBR dengan dimensi $15 \mathrm{~cm} \times 15 \mathrm{~cm} \times$ $30 \mathrm{~cm}$ dengan pencahayaan menggunakan sinar matahari serta debit aerasi sebesar 4,5 liter/menit. Media yang 
digunakan dalam MBBR adalah media Kaldnes 1 (K1).

\section{Bahan}

Limbah yang digunakan yaitu limbah cair hotel di Pekanbaru. Mikroalga yang digunakan yaitu Chlorella sp. dari Pusat Penelitian Alga Fakultas Perikanan dan Ilmu Kelautan Universitas Riau.

\section{Cara Kerja}

Preparasi Limbah Cair Hotel

Limbah cair hotel diambil sebanyak 11 Liter pada bak pengumpul kedua sesuai SNI 6989.59:2008 tentang Metode Pengambilan Contoh Air Limbah. Kemudian dilakukan uji nitrogen total dari limbah cair hotel tersebut.

\section{Perbanyakan Mikroalga Chlorella sp.}

Chlorella sp. diperbanyak dalam medium Dahril Solution selama sepuluh hari dengan cara menambahkan $100 \mathrm{ml}$ Chlorella sp. dan $400 \mathrm{ml}$ medium Dahril Solution kedalam 3,5 liter akuades. Sumber cahaya berasal dari cahaya matahari. Perbanyakan Chlorella sp. dilakukan hingga hingga pertumbuhan sel Chlorella sp. berada pada fase eksponensial dan mencukupi $1 \times 10^{6}$ $\mathrm{sel} / \mathrm{ml}$ (Oktafiani, 2013).

\section{Aklimatisasi}

Kultur mikroalga hasil perbanyakan dalam medium Dahril Solution akan melalui tahap aklimatisasi dalam reaktor sehingga kondisi alga hasil perbanyakan Chlorella sp. beradaptasi dengan limbah cair hotel yang di dalamnya terdapat media Kaldnes 1 (K1) (Filliazati dkk, 2013). Aklimatisasi dilakukan selama 6-10 hari hingga fase eksponensial mencapai 1 $\times 10^{6} \mathrm{sel} / \mathrm{ml}$. Tahap awal dilakukan dengan mencampurkan $50 \%$ alga hasil seeding dan $50 \%$ limbah cair hotel. Kemudian tahap berikutnya dilakukan dengan cara mencampurkan alga dari tahap pertama dan limbah cair hotel dengan rasio alga : limbah cair hotel sebesar $75 \%$ : 25\%.

\section{Percobaan Utama}

Pada percobaan utama, dilakukan kultivasi Chlorella sp. pada medium limbah cair hotel dalam MBBR dengan volume kerja 3 liter. Limbah cair hotel, suspensi alga dan media biocarrier dimasukkan kedalam MBBR sesuai dengan masingmasing variasi perlakuan, yaitu dengan variasi volume pengisian media biocarrier Kaldnes 1 (K1) sebesar 0\%, 10\%, 20\% dan $30 \% \mathrm{v} / \mathrm{v}$ (volume media: volume kerja). Konsentrasi suspensi alga yang dimasukkan pada percobaan ini adalah tetap yaitu sebesar $25 \%$ dari volume kerja (750 ml) (Zulfarina dkk, 2013). Dari setiap variasi tersebut diberikan sumber cahaya yang berasal dari sinar matahari. Dalam hal ini dilakukan perhitungan jumlah sel awal dari suspensi alga itu sendiri.

Analisa Jumlah Sel Mikroalga Chlorella sp. Perhitungan jumlah sel dilakukan setiap hari menggunakan thomacytometer diamati di bawah mikroskop cahaya dengan bantuan hand counter. Jumlah sel diukur pada proses biakan suspensi dan melekat. Mikroalga yang melekat pada biocarrier dicuci dengan akuades ke dalam wadah. Suspensi yang dihasilkan kemudian diencerkan hingga $10 \mathrm{ml}$ dan digunakan untuk mengukur parameter pertumbuhan (Zhuang dkk, 2016).

\section{Analisa $\mathrm{pH}$}

Pengukuran $\mathrm{pH}$ dilakukan dengan menggunakan $\mathrm{pH}$ meter dengan cara mencelupkan elektroda ke dalam contoh uji masing-masing reaktor sampai $\mathrm{pH}$ meter menunjukkan pembacaan yang tetap. Pengukuran $\mathrm{pH}$ dilakukan berdasarkan SNI 06-6989.11-2004.

\section{Analisa Suhu}

Pengukuran suhu dilakukan dengan menggunakan thermometer dan dilakukan untuk memastikan bahwa pengaruh suhu tidak akan menyebabkan terjadinya lisis pada sel mikroalga.

\section{Analisa MLSS}

MLSS diukur pada proses biakan suspensi dan melekat. Metode pengujian MLSS mengacu pada APHA, 1975. Berat awal dan akhir kertas saring diukur untuk mengukur konsentrasi MLSS. Pengurangan berat kertas saring tersebut dibandingkan dengan berat kertas saring 
awal untuk menentukan konsentrasi MLSS.

\section{Analisa Kadar Nitrogen Total}

Analisa kadar nitrogen total dilakukan dengan variasi waktu kontak $(0$, $1,2,3,4,5$ hari) yang mengacu pada SNI 4146-2013 menggunakan metode kjeldahl secara titrasi. Kadar nitrogen total dihitung melalui perkalian antara konsentrasi $\mathrm{HCl}$, $100 \%$, dan 14,008 . Kadar nitrogen total influen dan efluen diukur untuk menentukan efisiensi penyisihannya. Pengurangan kadar nitrogen total tersebut dibandingkan dengan kadar nitrogen total awal untuk menentukan nilai efisiensinya.

\section{HASIL DAN PEMBAHASAN \\ Pengaruh Volume Pengisian Kaldnes 1 \\ (K1) Terhadap Pertumbuhan Sel Chlorella sp. Berbasis Suspensi Selama Proses Pengolahan}

Pertumbuhan sel Chlorella sp. berbasis suspensi ditandai dengan peningkatan jumlah sel. Grafik jumlah sel mikroalga berbasis suspensi dapat dilihat pada Gambar 1.

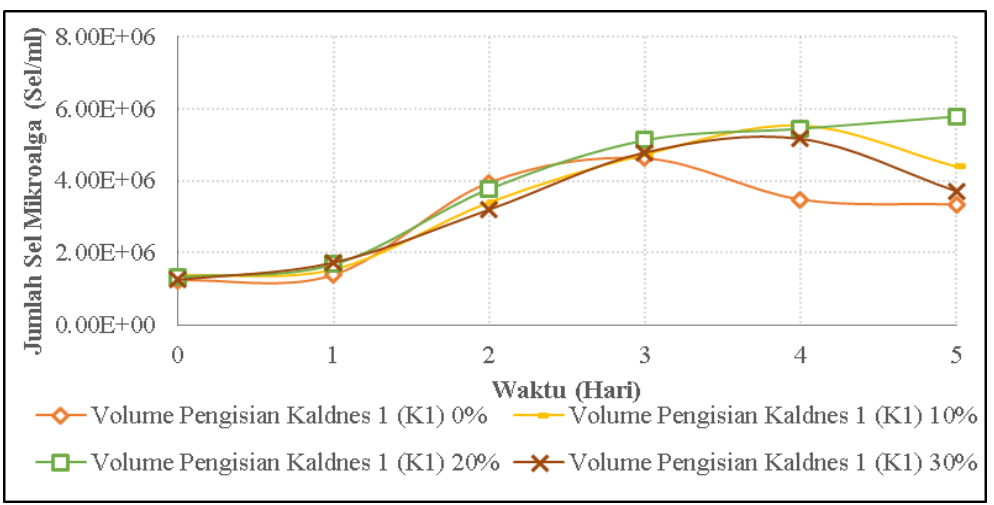

Gambar 1. Grafik Jumlah Sel Chlorella sp. Berbasis Suspensi pada Volume Pengisian Kaldnes 1 (K1) 10\%, 20\%, 30\% dan Kontrol

Volume pengisian Kaldnes 1 (K1) $20 \%$ mengalami fase eksponensial pada hari ke 2 hingga hari ke 5 sehingga tidak mengalami fase-fase berikutnya selama proses pengolahan. Hal ini dikarenakan pergerakan biocarrier yang seragam dapat mencegah lepasnya lapisan biofilm mikroalga ke dalam suspensi air limbah sehingga mikroalga dapat memanfaatkan nutrisi dengan baik tanpa bersaing dengan mikroalga lainnya.

Fase eksponensial juga dialami oleh volume pengisian Kaldnes 1 (K1) $10 \%$, $30 \%$ dan kontrol. Volume pengisian Kaldnes 1 (K1) 10\% mengalami fase eksponensial pada hari ke 2 hingga hari ke 4 dikarenakan lepasnya sel mikroalga yang melekat pada media biocarrier Kaldnes 1 (K1) sehingga dapat meningkatkan pertumbuhan mikroalga berbasis suspensi. Volume pengisian Kaldnes 1 (K1) 30\% tetap mengalami fase eksponensial pada pertumbuhan suspensi namun jumlah selnya tidak sebanyak volume pengisian Kaldnes 1 (K1) 10\% dan
$20 \%$. Hal ini dikarenakan volume pengisian Kaldnes 1 (K1) $30 \%$ berjumlah 636 buah sehingga dengan debit aerasi $4,5 \mathrm{~L} /$ menit yang telah ditetapkan menyebabkan pergerakan biocarrier menjadi lambat. Akibatnya, akumulasi mikroalga suspensi yang melekat pada media biocarrier meningkat. Perlakuan kontrol mengalami fase eksponensial yang tidak lama dibandingkan dengan adanya penambahan biocarrier. Menurut Vayenas (2011), kandungan bahan organik dan nutrisi menjadi berkurang dikarenakan tidak adanya biocarrier yang dapat mencegah akumulasi sel mikroalga berbasis suspensi.

Fase penurunan pertumbuhan pada volume pengisian Kaldnes 1 (K1) $30 \%$ terjadi pada hari ke 5 . Hal ini dikarenakan pada volume pengisian Kaldnes 1 (K1) yang tinggi, cahaya yang masuk ke dalam media suspensi terhalangi oleh akumulasi mikroalga yang melekat pada media biocarrier Kaldnes 1 (K1), sehingga mikroalga suspensi tidak memperoleh 
cahaya yang cukup dan akhirnya menurunkan produktivitas mikroalga berbasis suspensi (Vayenas, 2011). Selain itu, lapisan mikroalga biofilm yang terlalu padat dapat menghambat nutrisi dan $\mathrm{CO}_{2}$ untuk berdifusi ke lapisan biofilm terdalam sehingga menyebabkan sel mikroalga lisis (pecah). Sel mikroalga yang lisis dapat larut ke medium dan mengganggu pertumbuhan mikroalga berbasis suspensi (Hadiyanto dan Azim, 2012).

Pada volume pengisian Kaldnes 1 (K1) $10 \%$ mengalami fase penurunan pertumbuhan pada hari ke 5 . Hal ini dikarenakan pergerakan media biocarrier yang terlalu cepat sehingga menyebabkan lepasnya sel mikroalga yang melekat pada media biocarrier. Sedangkan pada perlakuan kontrol mengalami fase penurunan pertumbuhan pada hari ke 4 . Fase penurunan pertumbuhan yang lebih cepat dibandingkan perlakuan lainnya disebabkan oleh tidak adanya biocarrier yang dapat mencegah akumulasi sel mikroalga pada pertumbuhan suspensi dengan cara melekat pada media biocarrier Kaldnes 1 (K1). Dari kedua perlakuan tersebut menyebabkan sel mikroalga berbasis suspensi meningkat dan tidak diikuti dengan penambahan nutrisi. Hal ini sejalan dengan penelitian Istirokhatun dkk (2017), bahwa fase ini terjadi dikarenakan jumlah nutrisi yang tersedia tidak lagi dapat memenuhi kebutuhan konsumsi nutrisi mikroalga. Selain itu, fase penurunan pertumbuhan mikroalga dipengaruhi oleh akumulasi oksigen yang dihasilkan dari reaksi fotosintesis dan cahaya. Akumulasi oksigen dapat mempengaruhi keasaman sel (Hadiyanto dan Azim, 2012), sedangkan intensitas cahaya yang diserap oleh mikroalga dapat berkurang karena adanya bayangan dari mikroalga itu sendiri (self-shading) (Lebeharia, 2016).

Perlakuan kontrol mengalami fase stasioner pada hari ke 5 setelah fase penurunan pertumbuhan (hari ke 4) dengan jarak yang singkat. $\mathrm{Hal}$ ini didukung oleh penelitian Istirokhatun dkk (2017) yang menyatakan bahwa jarak fase penurunan pertumbuhan dan fase stasioner umumnya relatif singkat sehingga dibutuhkan perhitungan dengan intensitas yang lebih dari sekali dalam 24 jam sesuai dengan kebutuhan peneliti. Fase stasioner ditandai dengan peningkatan jumlah sel tidak terjadi lagi atau tetap sama dengan sebelumnya dikarenakan laju reproduksi dan laju kematian relatif sama.

\section{Pengaruh Volume Pengisian Kaldnes 1 (K1) Terhadap Pertumbuhan Sel Chlorella sp. Berbasis Biofilm Selama Proses Pengolahan}

Jumlah sel mikroalga berbasis biofilm dipengaruhi oleh volume pengisian Kaldnes 1 (K1). Grafik hubungan antara jumlah sel mikroalga melekat dan waktu pada variasi volume pengisian Kaldnes 1 (K1) $10 \%, 20 \%$ dan $30 \%$ dapat dilihat pada Gambar 2.

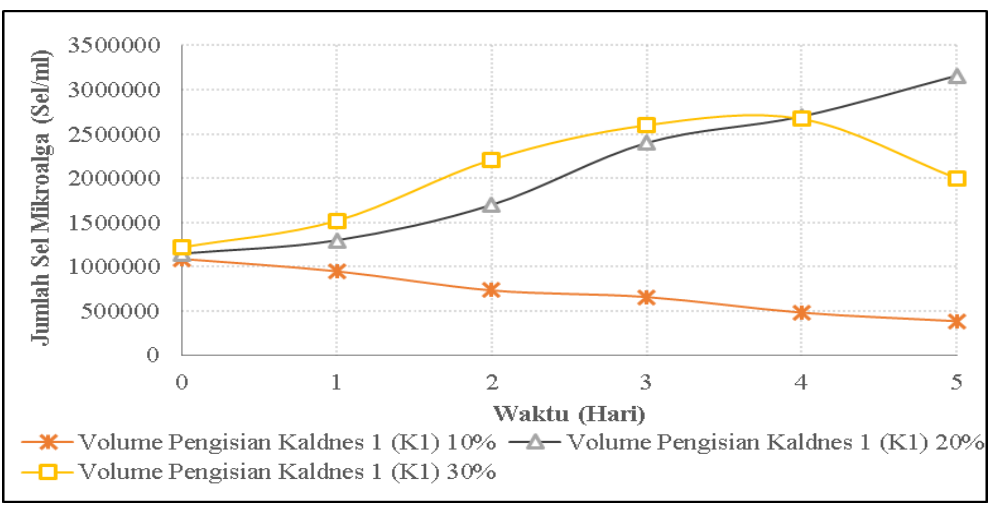

Gambar 2. Grafik Jumlah Sel Chlorella sp. Berbasis Biofilm pada Volume Pengisian Kaldnes 1 (K1) 10\%, 20\%, 30\% dan Kontrol

Pada volume pengisian Kaldnes 1 $20 \%$, jumlah sel mikroalga mengalami peningkatan hingga hari ke 5 dan merupakan jumlah sel tertinggi dari 
perlakuan lainnya. Pada volume pengisian Kaldnes 1 (K1) 20\% biocarrier bergerak seragam dan membantu mencegah terjadinya akumulasi kelebihan biomassa pada media biocarrier serta hilangnya biomassa karena tabrakan antar media. Selain itu, pada volume pengisian biocarrier $20 \%$ akan terbentuk lapisan biofilm yang tipis sehingga dapat meningkatkan difusi cahaya ke lapisan biofilm terdalam yang berguna untuk fotosintesis biofilm mikroalga (Vayenas, 2011).

(K1) $30 \%$ mengalami volume pengisian Kaldnes 1 pertumbuhan pada hari ke 5 . Hal ini dikarenakan penetrasi cahaya berkurang seiring dengan peningkatan volume pengisian Kaldnes 1 (K1). Ketika biofilm mencapai ketebalan tertentu, cahaya yang masuk ke lapisan biofilm menjadi terbatas karena terhalangi oleh mikroalga yang melekat itu sendiri sehingga terdapat mikroalga yang tidak mendapatkan cahaya dan akhirnya menurunkan produktivitas mikroalga. Sel mikroalga yang berada pada lapisan biofilm mikroalga dapat lisis atau pecah dan mengganggu pertumbuhan suspensi mikroalga. Menurut Vayenas (2011), ketebalan lapisan biofilm dapat menyebabkan terjadinya pembusukan sel endogen dan lisis (pecah) pada lapisan interior biofilm yang mengakibatkan kehilangan kemampuan untuk melekat pada media biocarrier. Selain itu, sebagian besar atau keseluruhan lapisan biofilm dapat terlepas dari media biocarrier dan larut ke dalam medium (Sloughing).

Jumlah sel mikroalga pada volume pengisian Kaldnes 1 (K1) $10 \%$ terus mengalami penurunan dimulai dari hari ke 1 hingga hari ke 5. Menurut Shresta (2013), penurunan jumlah sel mikroalga disebabkan oleh pergerakan biocarrier yang terlalu cepat dalam reaktor sehingga menyebabkan terjadinya tabrakan besar antar media biocarrier. Akibatnya, mikroalga yang melekat pada media biocarrier sangat mudah untuk lepas dan meningkatkan jumlah sel mikroalga berbasis suspensi.

\section{Pengaruh Perubahan pH Selama Proses Pengolahan}

$\mathrm{pH}$ pertumbuhan mikroalga pada tiap perlakuan mengalami perubahan selama proses pengolahan. Pada penelitian ini $\mathrm{pH}$ pertumbuhan mikroalga Chlorella sp. berkisar antara 7,54-9. Menurut Kuo dkk (2017), mikroalga Chlorella sp. dapat tumbuh dengan baik pada rentang $\mathrm{pH} 6,0-11,0$ sehingga $\mathrm{pH}$ pada penelitian ini masih berada dalam rentang pertumbuhan mikroalga Chlorella $\mathrm{sp}$. Adapun grafik perubahan $\mathrm{pH}$ selama proses pengolahan menggunakan mikroalga Chlorella sp. berbasis suspensi dan melekat dapat dilihat pada Gambar 3 berikut.

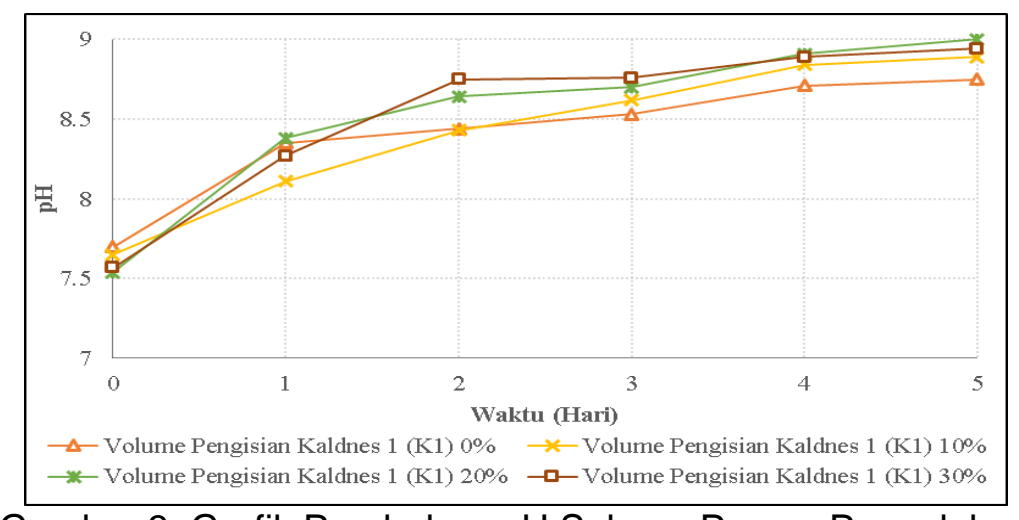

Gambar 3. Grafik Perubahan pH Selama Proses Pengolahan

Berdasarkan Gambar 3 dapat dilihat bahwa pada perlakuan volume pengisian Kaldnes 1 (K1) $20 \%$ selama proses pengolahan memiliki nilai $\mathrm{pH}$ tertinggi dengan peningkatan $\mathrm{pH}$ hingga 9 dari $\mathrm{pH}$ awal 7,54. Menurut Osorio dkk (2019), peningkatan $\mathrm{pH}$ dipengaruhi oleh pembentukan biofilm mikroalga. Peningkatan $\mathrm{pH}$ yang lebih tinggi dari pada perlakuan lainnya mengindikasikan 
bahwa pada volume pengisian Kaldnes 1 (K1) 20\%, pertumbuhan mikroalga berbasis suspensi dan melekat seimbang sehingga tiap sel mikroalga baik pada pertumbuhan berbasis suspensi dan melekat dapat mengalami pertumbuhan dan metabolisme sel ditandai dengan meningkatnya $\mathrm{pH}$. Hal ini sejalan dengan penelitian Zulfarina dkk (2013) yang menyatakan bahwa peningkatan $\mathrm{pH}$ terjadi diasumsikan sejalan dengan jumlah sel mikroalga, dimana meningkatnya jumlah sel mikroalga berarti meningkatkan metabolime dalam kultur mikroalga.

Nilai $\mathrm{pH}$ awal pada perlakuan volume pengisian Kaldnes 1 (K1) 10\%, $20 \%, 30 \%$, dan kontrol secara berturutturut adalah 7,65; 7,54; 7,57; dan 7,7. Menurut Muttaqin dan Wachda (2016), nilai $\mathrm{pH}$ yang rendah disebabkan oleh adanya penambahan limbah. Perbedaan $\mathrm{pH}$ pada tiap perlakuan disebabkan oleh volume limbah cair hotel yang tidak sama. Hal ini didukung oleh penelitian Purba (2011) yang mempelajari rasio volume air limbah terhadap alga. Hasil yang diperoleh menunjukkan bahwa volume air limbah berpengaruh terhadap persebaran nutrisi yang terdapat di dalam air limbah sehingga menyebabkan terjadinya perbedaan $\mathrm{pH}$ pada perlakuan awal. Nilai $\mathrm{pH}$ awal pada penelitian ini cenderung netral sehingga sangat mendukung pertumbuhan mikroalga Chlorella sp. $\mathrm{CO}_{2}$ berada dalam bentuk bebas di dalam air limbah pada lingkungan netral sehingga dapat berdifusi dengan mudah ke dalam sel mikroalga Chlorella sp. Akibatnya, $\mathrm{CO}_{2}$ sebagai sumber karbon utama untuk proses fotosintesis cukup tersedia sehingga proses metabolisme dapat berlangsung.

\section{Pengaruh Perubahan Suhu Selama Proses Pengolahan}

Pada penelitian ini suhu medium selama kultivasi berkisar antara $31-35^{\circ} \mathrm{C}$. Menurut Sutamihardja (1975), Chlorella sp. mampu hidup dan tumbuh secara optimum pada kisaran suhu $5-35^{\circ} \mathrm{C}$ sehingga kisaran suhu pada penelitian ini masih termasuk dalam rentang pertumbuhan Chlorella sp. Secara keseluruhan, jika dilihat dari grafik pertumbuhan mikroalga Chlorella sp. yang dikultivasi dalam medium limbah cair hotel tidak memberikan pengaruh yang signifikan terhadap laju pertumbuhannya. Ini dikarenakan kondisi suhu pada kultivasi mikroalga termasuk dalam rentang optimum bagi pertumbuhan Chlorella sp. Grafik perubahan suhu selama proses pengolahan dapat dilihat pada Gambar 4.

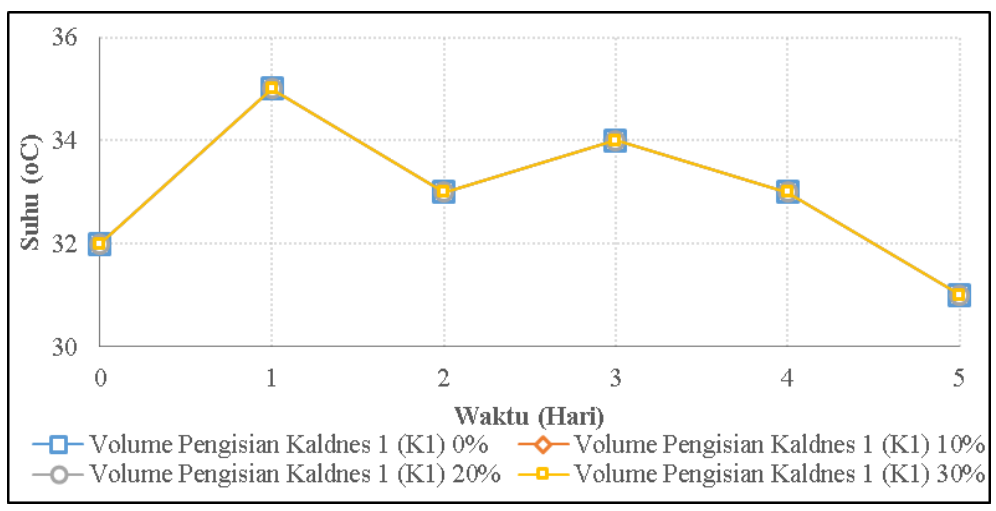

Gambar 4. Grafik Perubahan Suhu Selama Proses Pengolahan

Berdasarkan Gambar 4 dapat dilihat bahwa terjadi perubahan suhu pada tiap perlakuan. Perubahan suhu mengakibatkan terjadinya fluktuasi suhu dari awal hingga akhir perlakuan, tetapi fluktuasi suhu tidak mengganggu pertumbuhan mikroalga Chlorella sp. karena masih dalam rentang optimum pertumbuhannya. Suhu selama proses kultivasi mikroalga tergantung pada lokasi yang digunakan. Pada penelitian ini lokasi penelitian berada pada ruangan terbuka sehingga fluktuasi suhu dipengaruhi oleh kondisi cuaca selama proses pengolahan. 


\section{Pengaruh Konsentrasi MLSS Terhadap Pertumbuhan Berbasis Suspensi Selama Proses Pengolahan}

Ketersediaan mikroorganisme (termasuk bakteri) yang terdapat di dalam suspensi air limbah dapat diketahui melalui pengukuran Mixed Liqour Suspended Solid (MLSS) Adapun grafik konsentrasi MLSS pada proses pertumbuhan suspensi dapat dilihat pada Gambar 5.

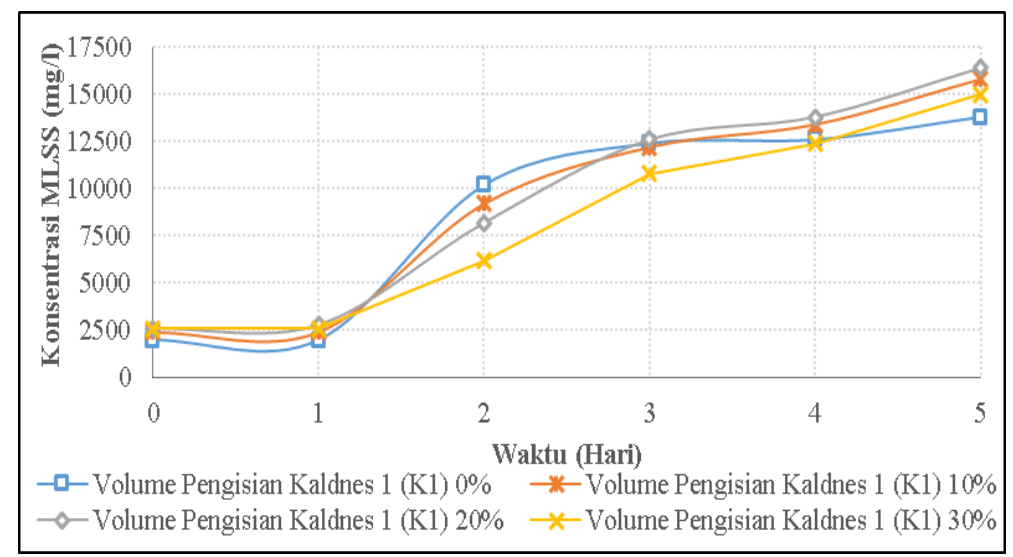

Gambar 5. Grafik Pengaruh Konsentrasi MLSS Terhadap Pertumbuhan Berbasis Suspensi

Nilai MLSS tertinggi terdapat pada volume pengisian Kaldnes 1 (K1) 20\% dengan MLSS sebesar $16400 \mathrm{mg} / \mathrm{l}$. Hal ini dikarenakan jumlah sel mikroalga pada reaktor tersebut tinggi. Mikroalga dapat melepaskan $\mathrm{O}_{2}$ yang dapat dimanfaatkan oleh mikroorganisme termasuk bakteri, sedangkan bakteri dapat melepaskan $\mathrm{CO}_{2}$ yang dapat diserap oleh mikroalga untuk berfotosintesis. Selain itu, adanya aerasi pada penelitian ini berpengaruh terhadap peningkatan MLSS. Volume pengisian Kaldnes 1 (K1) 20\% menyebabkan aerasi merata baik pada pertumbuhan suspensi maupun melekat. Menurut Hadiyanto dan Azim (2012), aerasi dapat meningkatkan aktifitas mikroba aerob sehingga dapat mengkonsumsi komponen organik yang ada pada air limbah.

\section{Pengaruh Konsentrasi MLSS Terhadap Pertumbuhan Berbasis Biofilm Selama Proses Pengolahan}

Grafik konsentrasi MLSS pada proses pertumbuhan melekat dapat dilihat pada Gambar 6.

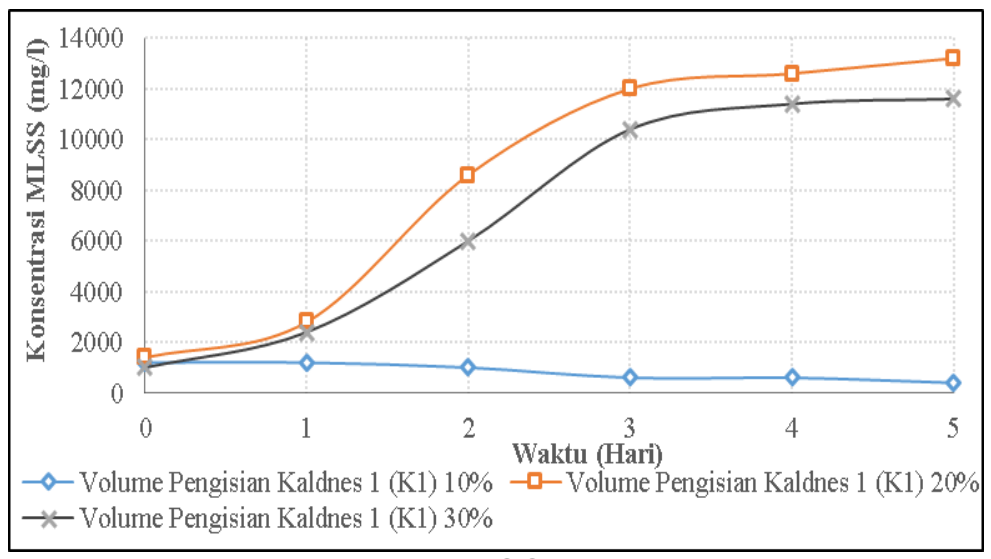

Gambar 6. Grafik Pengaruh Konsentrasi MLSS Terhadap Pertumbuhan Berbasis Biofilm

Perlakuan volume pengisian Kaldnes 1 (K1) 20\% memiliki konsentrasi MLSS yang lebih tinggi daripada perlakuan lainnya. Pada volume pengisian
Kaldnes 1 (K1) 20\% pergerakan Kaldnes 1 (K1) seragam dan dapat mencegah terjadinya tabrakan antar media Kaldnes 1 (K1) sehingga mampu mempertahankan 
mikroorganisme yang melekat pada media Kaldnes 1 (K1). Pada volume pengisian biocarrier $20 \%$ akan terbentuk lapisan biofilm yang tipis sehingga biomassa dapat memanfaatkan bahan organik dan nutrisi dengan baik. Banyaknya bahan organik yang dioksidasi dapat meningkatkan konsentrasi MLSS. Menurut Waizh (2018), semakin tinggi konsentrasi MLSS yang terdapat dalam sistem pengolahan mengindikasikan bahwa terdapat lebih banyak bahan organik yang dioksidasi.

\section{Pengaruh Volume Pengisian Kaldnes 1 (K1) Terhadap Konsentrasi dan Efisiensi Penyisihan Nitrogen Total}

Konsentrasi nitrogen total dan efisiensi penyisihan tiap perlakuan berbeda-beda. Adapun grafik konsentrasi dan efisiensi penyisihan nitrogen total serta hubungannya dengan total sel mikroalga pada proses pertumbuhan suspensi dan melekat selama proses pengolahan dapat dilihat pada Gambar 7.

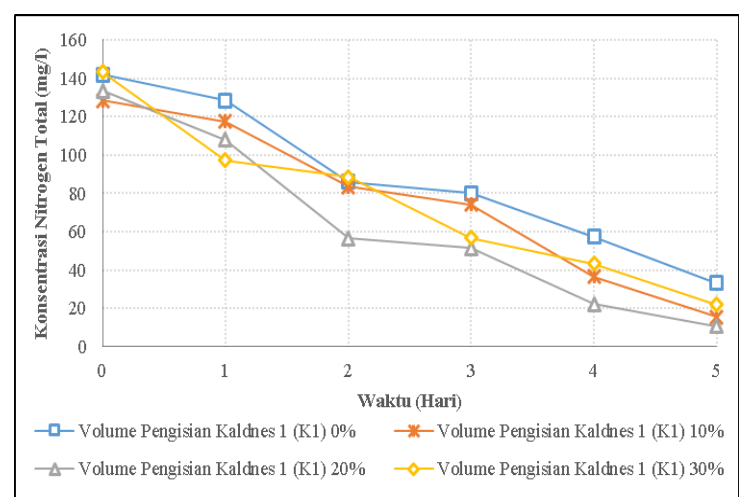

(a)

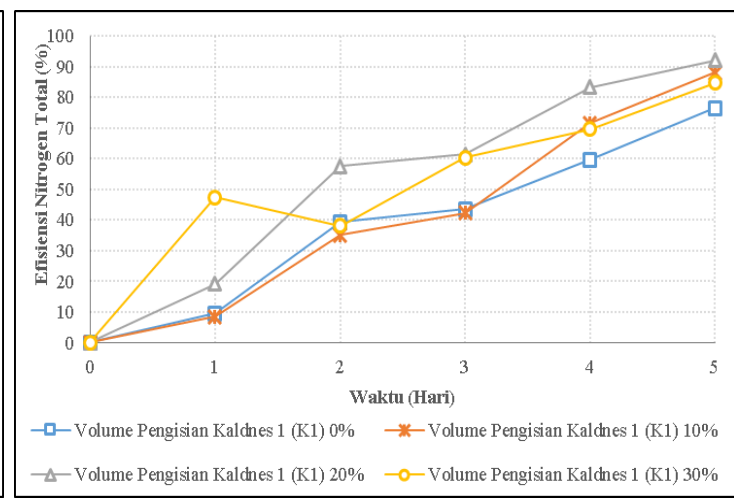

(b)

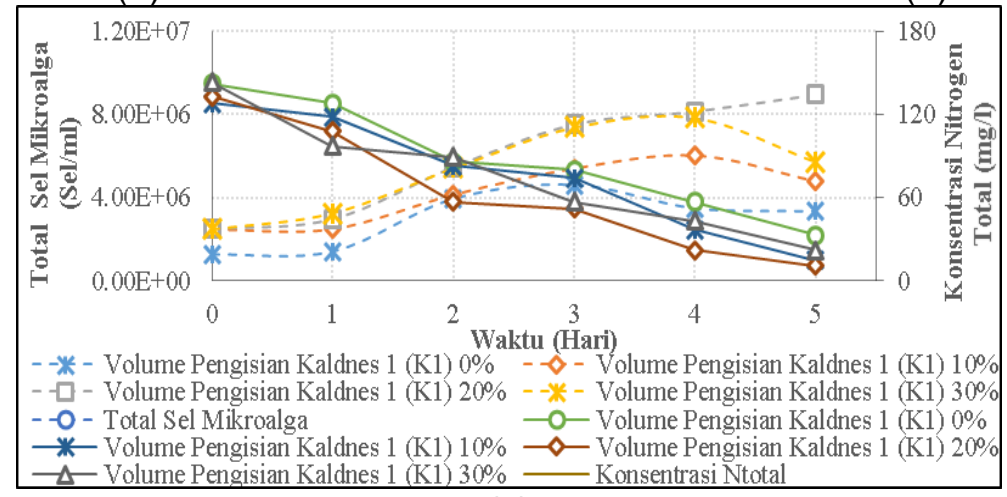

(c)

Gambar 7. (a) Grafik Konsentrasi Nitrogen Total (b) Grafik Efisiensi Nitrogen Total (c) Grafik Hubungan Total Sel Mikroalga Terhadap Konsentrasi Nitrogen Total

Pada volume pengisian Kaldnes 1 (K1) $20 \%$ memiliki efisiensi penyisihan nitrogen total tertinggi dengan tingkat efisiensi sebesar 91,96\%. Hal ini dikarenakan pada volume pengisian Kaldnes 1 (K1) 20\%, biocarrier bergerak seragam dan membantu mencegah terjadinya akumulasi kelebihan biomassa pada permukaan biocarrier serta hilangnya biomassa karena tabrakan antar media. Dengan demikian, biomassa yang melekat pada media biocarrier bisa mengkonsumsi lebih banyak bahan organik dan nutrisi dibandingkan dengan volume pengisian Kaldnes 1 (K1) 10\% dan $30 \%$. Pada volume pengisian Kaldnes 1 (K1) $10 \%$ dapat diamati bahwa biocarrier bergerak dengan cepat dalam reaktor sehingga dapat menyebabkan terjadinya tabrakan besar antar media biocarrier yang membuat mikroalga yang melekat pada media biocarrier sangat mudah untuk lepas, sedangkan pada volume pengisian Kaldnes 1 (K1) 30\% biocarrier bergerak perlahan dalam reaktor dan lapisan padat biomassa terbentuk sekitar 
permukaan biocarrier. Menurut Shresta (2013), Lapisan padat pada biofilm mikroalga dapat menghalangi cahaya, nutrisi dan bahan organik untuk berdifusi ke lapisan biofilm mikroalga terdalam.

Efisiensi penyisihan limbah pada perlakuan kontrol tanpa Kaldnes 1 (K1) memperoleh efisiensi penyisihan terendah sebesar 76,52\% dibandingkan dengan perlakuan dengan penambahan Kaldnes 1 (K1). Hal ini dikarenakan tidak adanya aktivitas penguraian pada biofilm mikroalga yang mendukung proses penguraian pada pertumbuhan suspensi. Pada proses pembentukan biofilm mikroalga terdapat EPS yang merupakan zat ekstraseluler yang mengandung protein, fospolipid dan polisakarida. Menurut Salama dkk (2015), EPS pada biofilm mikroalga memiliki kemampuan untuk menyerap garam anorganik seperti nitrogen yang bersumber dari limbah sebagai nutrisi untuk pertumbuhan mikroalga, sekaligus dapat menurunkan parameter pencemar. Hal ini didukung oleh penelitian Zhuang dkk (2016) yang menyatakan bahwa EPS pada biocarrier dapat meningkatkan sintesis protein di dalam sel dimana sintesis protein merupakan peran nitrogen dalam proses sintesis asam amino.

\section{Perbandingan Efisiensi Penyisihan Nitrogen Total pada Penelitian Lainnya Adapun perbandingan efisiensi penyisihan nitrogen total pada penelitian lainnya dapat dilihat pada Tabel 1 berikut.}

Tabel 1. Perbandingan Efisiensi Penyisihan Nitrogen Total pada Penelitian Lainnya

\begin{tabular}{|c|c|c|c|c|c|}
\hline No. & Mikroalga & $\begin{array}{c}\text { Biocarrier yang } \\
\text { Digunakan (Volume } \\
\text { Pengisian) }\end{array}$ & $\begin{array}{l}\text { Limbah yang } \\
\text { Digunakan }\end{array}$ & $\begin{array}{l}\text { Efisiensi } \\
(\%)\end{array}$ & Referensi \\
\hline 1. & $\begin{array}{l}\text { Chlorella sp. } \\
\text { dan } \\
\text { Scenedesmus } \\
\text { didominasi }\end{array}$ & $\begin{array}{c}\text { AnoxKaldnes K5 } \\
(50 \% \mathrm{v})\end{array}$ & $\begin{array}{l}\text { Limbah Cair } \\
\text { Domestik }\end{array}$ & 91,8 & $\begin{array}{c}\text { Hultberg dkk, } \\
2016\end{array}$ \\
\hline 2. & $\begin{array}{l}\text { Kombinasi } \\
\text { mikroalga dan } \\
\text { lumpur aktif }\end{array}$ & $\begin{array}{c}\text { AnoxKaldness }{ }^{\mathrm{TM}} \\
(1 / 3 \mathrm{v})\end{array}$ & $\begin{array}{l}\text { Limbah Cair } \\
\text { Industri } \\
\text { Pemurnian Gula } \\
\text { (Molase) }\end{array}$ & 35 & $\begin{array}{l}\text { Tsioptsias } \\
\text { dkk, } 2016\end{array}$ \\
\hline 3. & Chlorella sp. & $\begin{array}{c}\text { Kaldnes } 1(\mathrm{~K} 1) \\
(20 \% \mathrm{v})\end{array}$ & $\begin{array}{c}\text { Limbah Cair } \\
\text { Hotel }\end{array}$ & 91,96 & Penelitian ini \\
\hline
\end{tabular}

Berdasarkan Tabel 1 dapat dilihat bahwa pengolahan limbah cair hotel menggunakan mikroalga Chlorella sp. dan biocarrier Kaldnes 1 (K1) menghasilkan efisiensi tertinggi dibandingkan penelitian sebelumnya. Hal ini dikarenakan pergerakan biocarrier yang seragam menjadikan lapisan biofilm mikroalga tipis sehingga nutrisi dapat berdifusi ke lapisan biofilm mikroalga terdalam. Penelitian Hultberg dkk (2016) membuktikan bahwa pada volume pengisian biocarrier yang tinggi tetap dapat menyisihkan nitrogen total, sedangkan penelitian Tsioptsias dkk (2016) menghasilkan efisiensi yang rendah dikarenakan terdapat endapan mikroalga di dinding reaktor yang berbentuk tabung sehingga mengurangi penetrasi cahaya dalam reaktor.

\section{SIMPULAN DAN SARAN}

Berdasarkan hasil dan pembahasan yang telah dilakukan dapat disimpulkan bahwa (1) efisiensi penyisihan nitrogen total tertinggi selama proses pengolahan terjadi pada MBBR dengan volume pengisian Kaldnes 1 (K1) $20 \%$ dengan efisiensi penyisihan nitrogen total $91,96 \%$ pada hari kelima. (2) Waktu kontak terbaik selama proses pengolahan terjadi pada hari kelima. Semakin lama waktu kontak pada penelitian ini maka semakin besar efisiensi penyisihan nitrogen total. (3) Jumlah sel mikroalga Chlorella sp. tertinggi pada pertumbuhan suspensi dan melekat berturut-turut yaitu $5,78 \times 10^{6}$ $\mathrm{sel} / \mathrm{ml}$ dan $3,16 \times 10^{6} \mathrm{sel} / \mathrm{ml}$.

Saran yang dapat diberikan untuk penelitian selanjutnya adalah (1) perlu 
dilakukan kultivasi mikroalga hasil aklimatisasi pada medium limbah cair hotel dengan meningkatkan waktu kontak hingga mencakuo seluruh fase pertumbuhan dari mikroalga. (2) penelitian lanjutan dengan menambahkan bakteri untuk mempercepat proses pembentukan biofilm mikroalga dan meningkatkan kinerja alga dalam menyisihkan bahan organik dalam limbah cair hotel.

\section{DAFTAR PUSTAKA}

Anisa, A., \& Herumutri, W. (2017). Pengolahan Limbah Domestik Menggunakan Moving Bed Biofilm Reactor (MBBR) dengan Proses Aerobik-Anoksik Untuk Menurunkan Nitrogen. Jurnal Teknik ITS, 6(2), 361-366.

Filliazati, M., Apriani, I., dan Zahara, T. A. (2013). Pengolahan Limbah Cair Domestik Dengan Biofilter Aerob Menggunakan Media Bioball dan Tanaman Kiambang. Jurnal Teknologi Lingkungan Lahan Basah, 1(1), 1-10.

Hadiyanto., dan Azim, M. (2012). Mikroalga Sumber Pangan dan Energi Masa Depan. Semarang: UPT UNDIP Press.

Hultberg, M., Olsson, L. E., Birgersson, G., Gustafsson, S., dan Sievertsson, B. (2016). Microalgal Growth in Municipal Wastewater Treated in an Anaerobic Moving Bed Biofilm Reactor. Journal of Bioresource Technology, 19-23.

Imania, A. W., dan Herumurti, W. (2018). Pengolahan Lindi Menggunakan Moving Bed Biofilm Reactor (MBBR) dengan Pretreatment Ozon untuk Menurunkan Konsentrasi COD. Jurnal Teknik ITS, 7(1), 203-206.

Istirokhatun, T., Aulia, Mustika., Sudarno. (2017). Potensi Chlorella sp. Untuk Menyisihkan COD dan Nitrat dalam Limbah Cair Tahu. Jurnal Presipitasi:
Media Komunikasi dan Pengembangan Teknik Lingkungan, 14(2), 88-96.

Kuo, C. M, Lin, H. T., Yang, Y. C., Zhang, W. X., Lai, J. T., Wu, H. T., Chang, J. S., dan Lin, C. S. (2017). Ability of an Alkali-Tolerant Mutant Strain of The Microalga Chlorella sp. AT1 to Capture Carbon Dioxide for Increasing Carbon dioxide Utilization Efficiency. Journal of Bioresource Technology, 244, 243-251.

Lebeharia, S. M. 2016. Pertumbuhan dan Kualitas Biomassa Spirulina Platensis yang di Produksi pada Media Zarouk Modifikasi. Skripsi, Fakultas Sains dan Teknologi, Universitas Islam Negeri Syarif Hidayatullah, Jakarta.

Muttaqin, S. S., dan Wachda. (2016). Peningkatan Kandungan Lipid pada Kultur Arthrospira Maxima (Setchell \& N.L Gardner) sebagai Biodiesel dengan Medium Limbah Cair Tahu. Journal of Inovation Science Writing Competition (Instinct).

Ningtias, B. C., Moersidik, S. S., Priadi, C. R., dan Said, N. I.. (2015). Pengolahan Air Limbah Domestik Dengan Anoksik-Aerobik Moving Bed Biofilm Reactor (Studi Kasus: Penyisihan Amonia dan Karbon Dalam Air Limbah Domestik). JAI, 8(2), 177-188.

Oktafiani, M. 2013. Pengaruh Konsentrasi Nutrien dan Konsentrasi Bakteri Pada Produksi Alga Dalam Sistem Bioreaktor Proses Batch. Skripsi, Fakultas Teknik Sipil dan Perencanaan, Institut Teknologi Sepuluh Nopember, Surabaya.

Osorio, J. H. M., Pinto, G., Pollio A., Frunzo, L., Lens, P. N. L., dan Esposito, G. (2019). Start-up of a nutrient removal system using Scenedesmus vacuolatus dan Chlorella vulgaris biofilms. Journal of 
Biosources dan Bioprocessing, 6(27):1-16.

Paniagua, M. J. (2015). Microalgal Nutraceuticals. Mexico: Handbook of Marine Microalgae.

Pemerintah Kota Pekanbaru. 2017. Dokumen Informasi Kinerja Pengelolaan Lingkungan Hidup. Pemko. Pekanbaru.

Pinjankar, A. B., Jagtap, R. D., Solanke, C. K., dan Mehta, H. H. (2017). The Moving Bed Biofilm Reactor (MBBR). International Advanced Research Journal in Science, 4(3), 63-66

Purba, N. T., 2011. Pemanfaatan Mikroalga Untuk Pengolahan Limbah dan Potensinya Sebagai Bahan Baku Biofuel. Skripsi, Fakultas Teknik, Universitas Indonesia, Depok.

Said, N. I., dan Santoso, T. I. (2015). Penghilangan Polutan Organik dan Padatan Tersuspensi di dalam Air Limbah Domestik Dengan Proses Moving Bed Biofilm Reactor (MBBR). JAl, 8(1), 33-45.

Said, N. I., dan Sya'bani, M. R. (2014). Penghilangan Amoniak di dalam Air Limbah Domestik dengan Proses Moving Bed Biofilm Reactor (MBBR). JAl, 7(1), 44-65.

Salama, Y., Chennaoui, M., Sylla, A., Mountadar, M., Rihani, M., dan Assobhei, O. (2015). Characterization, Structure, and Function of Extracelullar Polymeric Substances (EPS) of Microbial Biofilm in Biological Wastewater Treatment Systems: A Review. Journal of Desalination and Water Treatment, 1-18.

Shresta, A. 2013. Specified Moving Bed Biofilm Reactor in Nutrient removal from Municipal Wastewater. Tesis, Faculty of Engineering and
Information Technology, University of Technology, Sydney.

Sui, Z., Gizaw, Y., dan Miller, B. J. N. (2012). Extraction of Polysaccharides From A Species Of Chlorella. Carbohydrate Polymers, 90(1), 1-7.

$\begin{array}{llll}\text { Sutamihardja, } & \text { R. } & \text { T. } & \text { M. } 1975 .\end{array}$ Pengetrapan Chlorella sp. dan Ganggang Lainnya sebagai Penambah Bahan Makanan di Indonesia. Bogor: IPB.

Tsioptsias, C., Lionta, G., Deligiannis A., dan Samaras, P. (2016). Enchancement of The Performance of A Combined Microalgae-Activated Sludge System For The Treatment of High Strength Molasses Wastewater. Journal of Environmental Management, 30, 17.

Vayenas, D. V. (2011). Attached Growth Biological Systems in The Treatment of Potable Water and Wastewater. Journal of Comprehensive Biotechnology, 371-383.

Waizh, N. T. (2018). Pengaruh Densitas Alga dan Kedalaman Reaktor Terhadap Penurunan BOD \& COD Limbah Cair Domestik. Dspace Repository.

Zhuang, L. L., Azimi, Y., Yu, D., Wang, W. L., Wu, Y. H., Dao, G. H., dan Hu, H. Y. (2016). Enhanced Attached Growth of Microalgae Scenedesmus. LXI Through Ambient Bacterial PreCoating Of Cotton Fiber Carriers. Journal of Bioresource Technology, 1-31.

Zulfarina. Sayuti, I., dan Putri, H. (2013). Potential Utilization of Algae Chlorella Pyrenoidosa for Rubber Waste Management. Journal of Technology, 1(3). 